\title{
EFFECT OF GAMMA IRRADIATION COMBINED WITH B.T.BIOCIDE TREATMENTS ON SOME INSECT PESTS IN LABORATORY
}

\author{
REDA, A. M. AMER, M. A. AHMED and A. E. HATEM \\ Plant Protection Research Institute, Agriculture Research Center, Dokki, Giza, Egypt.
}

(Manuscript received $1^{\text {st }}$ November 2011)

\begin{abstract}
The study was done in the laboratories of Bollworms, Leafworm and piercing \& sucking Research Departments of Plant Protection Research Institute during 2010. The tested pests and the biocide, Protecto were exposed to gamma irradiation doses at National Center for Radiation Research and Technology, Egypt.

Three tested insects were tested includes: pink bollworm, Pectinophora gossypiella (Saund.) newly hatched and fourth instar larvae, cotton leafworm, Spodoptera littoralis (Boisd.) $4^{\text {th }}$ instar larvae and the nymph \& adult of cowpea aphid, Aphis craccivora (Koch). Insects were exposed to three doses of gamma irradiation, 150, $250 \& 350$ Gy. Also, the biocide compound, Protecto (Bacillus thuringiensis, Kurs.) was applied on the same pests to assess the insecticidal activity of Protecto in three combinations (Protecto +150 Gy, Protecto +250 Gy and Protecto +350 Gy).

Data showed that the tested $Y$ - irradiation doses of 150, 250 and $350 \mathrm{~Gy}$ increased the newly hatched larval mortality of $P$. gossypiella to 52,65 and $85 \%$ at zero day, respectively. While, it was reached to $100 \%$ kill at third day for $350 \mathrm{~Gy}$ and fifth day for 150 and $250 \mathrm{~Gy}$. Larval mortality of $P$. gossypiella fourth instar was reached to $100 \%$ at eight and tenth days after radiation. Also, the larval mortality of $S$. littoralis fourth instar larvae was reached to $100 \%$ at tenth and twelfth days after treatment, respectively. While, $A$. craccivora adults and nymphs mortality was reached to $100 \%$ at zero day just after treatment.

Generally, $\mathrm{LC}_{50}{ }^{\prime} \mathrm{S}$ on subjected insects treated with Protecto and exposed to gamma doses were lower than untreated Protecto.

The aim of present work was to evaluate the insecticidal activity of the biocide Protecto in combination with $\gamma$-irradiation exposure against three key insect pests in laboratory.

Key words: Protecto, gamma irradiation, P. gossypiella, $S$. littoralis, A. craccivora
\end{abstract}

\section{INTRODUCTION}

The pink bollworm, Pectinophora gossypiella (Saund.) (Lepidoptera : Gelechiidae) is the most destructive pest infesting cotton bolls, okra, hibiscus and Jute in Egypt causing quantity and quality decrease of crops. The cotton leaf worm, Spodoptera littoralis (Boisduval) (Lepidoptera : Noctuidae) devastates a large host range of more than 120 host plants (Hatem et al. 2009). Also, cowpea aphid, Aphis craccivora (Koch) (Homoptera : Aphididae) is a threat to cowpea growers in all over the country. Both 
nymphs and adults suck plant sap and cause serious damage right from the seedling to pod bearing stage. Due to heavy infestation, young seedlings succumb to death, whereas the older plants show severe symptoms and finally resulting in yield reduction. (Rabindra and Ramanujam, 2007).

The overuse of insecticides eventually created many of the problems as resistance, environmental pollution and adverse effects on the non-target organisms. In order to avoid the insecticidal hazards, there is a great need to develop alternative control agents with new mode of action. Among these agents is gamma irradiation as a genetic control method. Genetic pest suppression is unique among biological methods in that it involves the release of genetically modified insects to control the same species (Soon, 1986). The irradiated biocide, Dipel-2x with doses of 5, 10, 20, $40 \& 80$ Gy activated its insecticidal efficiency against two stages of the harmful $P$. gossypiella i.e. newly hatched larvae and eggs of 1-4 day old in laboratory and field experiments during seasons of 2004 and 2005 (Amer, 2006). The Inherited effects of gamma irradiation doses of 50, 75, 100, 125, $150 \& 200$ Gy were studied on males and females irradiated as 7-day old pupae until the F3 generation. The fecundity and egg hatch were reduced, while, the mating and sperm did not affect. Also, increased the larval and pupal mortality of S.littoralis (Sallam and Ibrahim 1993). Moy et al., (1997) suggested that gamma irradiation $0.15,0.5,0.7,2.0$ and $4.0 \mathrm{KGy}$ were promising as a quarantine treatment for some fresh herbs and ornamental plants in Hawaii against aphids, mites and thrips.

Protecto, $B$. thuringiensis was used to control successfully the newly hatched larvae of $P$. gossypiella as reported by Amer \& El-Nemaky (2008). In addition, Pawar and Borikar, 2005 reported that microbial pesticides are one such alternative to tackle insecticide resistant population of $S$. litura. Saranya, et al. (2010) found the same result against the cowpea aphid, $A$. crassivora (Koch). Chen, et al. (2011) indicated that consecutive cultivation by genetically modified cottons with BT genes can result in persistence of Cry1AC proteins and negatively affect soil microbial and biochemical properties.

Thus, the aim of the present study was to evaluate the combined effects of the biocide compound, Bacillus thuringiensis, Kurs. (Protecto) exposed to gamma irradiation at doses of 150, 250 and 350 Gy against key destructive insect pests i.e. the pink bollworm, P. gossypiella, cotton leaf worm, $S$. littoralis and cowpea aphid, $A$. craccivora. 


\section{MATERIALS AND METHODS}

\section{Tested biocide}

Protecto, is a commercial formulation of Bacillus thuringiensis (Kurs.) and it is a product of Special Unit for Producing Bioinsecticides, Plant Protection Research Institute, Agriculture Research Center, Egypt, with 32000 international toxicity units (spores and protein crystals) per mg. The active ingredient is $6.4 \%$ W.P and the application rate is $300 \mathrm{gm} /$ feddan.

Protecto $6.4 \%$ W.P was exposed to gamma irradiation doses of $150,250, \& 350$ Gy. All irradiations were done by a $\mathrm{Co}^{60}$ Hendy Cell Research, National Center for Radiation Research and Technology, delivered at a dose rate $3.61 \mathrm{KGy} / \mathrm{h}$.

\section{Tested pests}

A laboratory strain of the pink bollworm, P. gossypiella was reared at Bollworms Department, Plant Protection Research Institute, Agriculture Research Center on semi artificial diet as described by Rashad and Ammar (1985). Rearing conditions were adjusted at $27 \pm 1^{\circ} \mathrm{C}$ and $65-75 \% \mathrm{RH}$.

The cotton leafworm, $S$. littoralis fourth instars larvae of laboratory strain was reared at Cotton leafworm Department, Plant Protection Research Institute, Agriculture Research Center on castor oil leaves, Ricinus communis (L.). Rearing of insects was conducted following the technique described by El-Defrawi et al. (1964). Rearing conditions were adjusted at $27 \pm 1^{\circ} \mathrm{C}$ and $65-75 \% \mathrm{RH}$.

The cowpea aphids, $A$. craccivora adults and nymphs of laboratory strain was reared at Sucking and Piercing Department, Plant Protection Research Institute, Agriculture Research Center on Ficia faba beans leaves. Rearing conditions were adjusted at $27 \pm 1^{\circ} \mathrm{C}$ and $65-75 \% \mathrm{RH}$.

\section{Effect of gamma irradiation doses on tested pests}

Twenty five larvae of the newly hatched and fourth instar of $P$. gossypiella in 2 gm semi artificial diet Petri-dishes were exposed to gamma irradiation doses of 150, $250 \& 350 \mathrm{~Gy}$. Five replicates for each $y$-irradiation doses were used and the control group was done. The larval mortality percent was recorded at 0 (the same day of exposure to gamma irradiation), $1,3 \& 5$ days after treatment for newly hatched and added $8 \& 10$ days for $4^{\text {th }}$ instars larvae.

Twenty five of fourth instar larvae of $S$. littoralis in castor oil leaves Petri-dishes were exposed to gamma irradiation doses of 150, 250 \& 350 Gy. Five replicates for each gamma dose used and the control was done. The larval mortality percent was recorded at $0,1,3,5,8,10 \& 12$ days after treatments. 
Bean leaves infested by twenty five individuals of aphid adults and nymphs of $A$. craccivora were prepared in glass vials $(4 \times 8 \mathrm{~cm})$, closed by muslin tighten by rubber band and exposed to gamma irradiation doses of 150, 250 \& 350 Gy. Five replicates for each gamma dose used and the control was done. The adult or nymph aphid's mortality percent was recorded.

\section{Insecticidal activity of Protecto biocide treatment combined with gamma doses}

\subsection{Pink bollworm, P. gossypiella.}

Two gm of semi artificial diet/Petri-dish (9 cm diameter) were mixed with $1 \mathrm{ml}$. of each concentration from the tested biocide. The Petri- dish used as control was treated with $1 \mathrm{ml}$. distilled water mixed with $2 \mathrm{gm}$ artificial diet. The tested concentrations were $40,20,10,5 \& 2.5 \mathrm{gm} / \mathrm{L}$. Twenty five of newly hatched and fourth instar larvae of $P$. gossypiella were left starving for 4 hours, then exposed for about 6 hours (newly hatched) and one hour ( $4^{\text {th }}$ instar larvae) to Protecto, Protecto + $150 \mathrm{~Gy}$, Protecto $+250 \mathrm{~Gy}$ \& Protecto $+350 \mathrm{~Gy}$ and kept at $27 \pm 1^{\circ} \mathrm{C}$ and $65-75 \%$ R.H Then after the alive larvae were transferred to untreated artificial diet for 72 hours after treatment.

\subsection{Cotton leafworm, $S$. littoralis.}

Dipping technique was used at the present work. The castor oil leaves were dipped in tested compound concentrations of 40, 20, 10, $5 \& 2.5 \mathrm{gm} / \mathrm{L}$ of the Protecto, Protecto $+150 \mathrm{~Gy}$, Protecto $+250 \mathrm{~Gy} \&$ Protecto $+350 \mathrm{~Gy}$. The control was done by castor oil leaves dipping in water only. Five replicates/ concentration/ tested biocide were used. The leaves were left until water evaporation and kept in glass jars $(11 \times 22 \mathrm{~cm})$. Each jar was supplied with 25 fourth instar larvae after starvation period for 4 hours and maintained under $27 \pm 1{ }^{\circ} \mathrm{C}$. Then after the numbers of alive and dead larvae were counted three days after treatment.

\subsection{Cowpea aphid, A. craccivora.}

Slide dipping technique was used at the present work according to Dennehye et al., (1983). Adults or nymphs aphid of $A$. craccivora (Koch.) were placed on a double slide sticky tape that had been fixed to micro slide. The slides were then dipped for 20 seconds into the concentrations of 40, 20, 10, $5 \& 2.5 \mathrm{gm} / \mathrm{L}$ of the Protecto, Protecto + 150 Gy, Protecto + 250 Gy and Protecto + 350 Gy. Five replicates/ concentration/ tested biocide were used. Each slide was prepared by 10 aphid adults or nymphs of cowpea aphid/replicate. After treatments, aphids were kept in an incubator at 24 $\pm 2^{\circ} \mathrm{C}$. A control group that was dipped into water only was also involved. Mortalities were recorded after 24 hours and aphids unable to move their legs when lightly brushed were counted as dead. 
The mortality percentages as a result of gamma irradiation exposure were corrected by Abbott (1925).

$\mathrm{LC}_{50} \& \mathrm{LC}_{90}$ values were obtained by software computer probane. The efficiency of different insecticides could be measured by using Sun 's equation (1950) as follows:

$\mathrm{LC}_{50}\left(\mathrm{LC}_{90}\right)$ of the compound $\mathrm{A}$

Toxicity index $X 100$

$\mathrm{LC}_{50}\left(\mathrm{LC}_{90}\right)$ of the compound $\mathrm{B}$

Where $A$ : is the most effective compound (The compound that had the highest toxicity or the lowest value of $\mathrm{LC}_{50}$ or 90 ).

$\mathrm{B}$ : is the other (each) tested compound.

Larval mortality percentages, was analyzed using Costat statistical program software, 1990 and Duncan's multiple range test (Duncan, 1955) at 5\% probability level to compare the differences among time means.

\section{RESULTS AND DISCUSSION}

\section{Insecticidal activity of gamma irradiation exposure against the tested insect pests:}

\subsection{Pink bollworm, P. gossypiella.}

\subsubsection{Newly hatched larvae:}

Gamma irradiation dose of 150 Gy caused $52 \%$ mortality at zero day (the same day of exposure to gamma irradiation) when the newly hatched larvae exposed to it. The percent increased to 65 and 85\% for doses of 250 and 350 Gy as shown in Table (1). Amer (2006 a) reported that the percent larval mortality ranged between $39.04-$ $48.44 \%$ for $5-80 \mathrm{~Gy}$, because to its effect on the acetylcholine esterase after feeding on the irradiated diet.

Mortality percent were increased to $71,80 \& 95 \%$ at one day after exposure to gamma irradiation of $150,250 \& 350 \mathrm{~Gy}$, respectively. The mortality reached to 84,92 $\& 100 \%$ after 3 - days. While, the larval mortality reached to $100 \%$ with 150 and 250 Gy at $5^{\text {th }}$ day. No mortality percent was recorded happened in the control group. 
Table 1. Effect of gamma irradiation doses on the mortality percent of $P$. gossypiella newly hatched larvae.

\begin{tabular}{|c|c|c|c|c|}
\hline \multirow{2}{*}{$\begin{array}{c}\text { Gamma } \\
\text { doses } \\
\text { (Gy) }\end{array}$} & 0-day & 1-day & 3-day & 5-day \\
\cline { 2 - 5 } Control & $0^{\mathrm{d}}$ & $0^{\mathrm{d}}$ & $0^{\mathrm{d}}$ & $0^{\mathrm{b}}$ \\
\hline 150 & $52^{\mathrm{c}}$ & $71^{\mathrm{c}}$ & $84^{\mathrm{c}}$ & $100^{\mathrm{a}}$ \\
\hline 250 & $65^{\mathrm{b}}$ & $80^{\mathrm{b}}$ & $92^{\mathrm{b}}$ & $100^{\mathrm{a}}$ \\
\hline 350 & $85^{\mathrm{a}}$ & $95^{\mathrm{a}}$ & $100^{\mathrm{a}}$ & - \\
\hline LSD $_{0.05}$ & 5.408 & 2.105 & 2.663 & - \\
\hline
\end{tabular}

Means in the same row followed by the same letter are not significantly different at $p<0.05$.

Table 2. Effect of gamma irradiation doses on the mortality percent of $P$. gossypiella $4^{\text {th }}$ instar larvae.

\begin{tabular}{|c|c|c|c|c|c|c|}
\hline \multirow{2}{*}{$\begin{array}{c}\text { Gamma } \\
\text { Doses } \\
\text { (Gy) }\end{array}$} & \multicolumn{6}{|c|}{ \% Larval mortality after } \\
\cline { 2 - 7 } & 0-day & 1-day & 3-day & 5-day & 8-day & 10-day \\
\hline Control & 0 & $0^{\mathrm{c}}$ & $0^{\mathrm{d}}$ & $0^{\mathrm{d}}$ & $0^{\mathrm{d}}$ & $0^{\mathrm{b}}$ \\
\hline 150 & 0 & $8^{\mathrm{b}}$ & $38^{\mathrm{c}}$ & $65^{\mathrm{c}}$ & $86^{\mathrm{c}}$ & $100^{\mathrm{a}}$ \\
\hline 250 & 0 & $10^{\mathrm{b}}$ & $53^{\mathrm{b}}$ & $71^{\mathrm{b}}$ & $91^{\mathrm{b}}$ & $100^{\mathrm{a}}$ \\
\hline 350 & 0 & $14^{\mathrm{a}}$ & $65^{\mathrm{a}}$ & $90^{\mathrm{a}}$ & $100^{\mathrm{a}}$ & - \\
\hline $\mathrm{LSD}_{0.05}$ & - & 2.306 & 3.522 & 2.321 & 2.927 & - \\
\hline
\end{tabular}

Means in the same row followed by the same letter are not significantly different at $p<0.05$.

\subsubsection{Fourth instar larvae:}

Fourth instar larvae of the pink bollworm, P. gossypiella were exposed to gamma irradiation doses of $0.0,150,250$ and $350 \mathrm{~Gy}$. The larval mortality increased with $Y$ doses increasing (Table 2). The larval mortality was $0.0 \%$ at zero time after treatment. The mortality was ranged between 8 and $14 \%$ at $1^{\text {st }}$ day after exposure to 150- $350 \mathrm{~Gy}$. The fourth instar larvae completely killed at $8^{\text {th }}$ day with $350 \mathrm{~Gy}$ and at $10^{\text {th }}$ day after exposure to 150 and $250 \mathrm{~Gy}$. No larval mortality was recorded in the control group. 


\subsection{Cotton leafworm, $S$. littoralis.}

Table (3) showed that untreated larvae group of $S$. littoralis recorded was $0.0 \%$ mortality. When the fourth instar larvae was exposed to gamma irradiation doses of 150, 250 and $350 \mathrm{~Gy}$, no mortality recorded at zero day after treatment. The larval mortality recorded 8,13 and $18 \%$ at 1-day after exposure to 150,250 and $350 \mathrm{~Gy}$, respectively. The mortality percent were increased to $100 \%$ at the 10 -day after exposure to dose of $350 \mathrm{~Gy}$. While, the larvae exposed to 150 and 250 Gy were completely killed at 12-day after treatment.

Table 3. Effect of gamma irradiation doses on the mortality percent of $S$. littoralis $4^{\text {th }}$ instar larvae.

\begin{tabular}{|c|c|c|c|c|c|c|c|}
\hline \multirow{2}{*}{$\begin{array}{c}\text { Gamma } \\
\text { doses } \\
\text { (Gy) }\end{array}$} & \multicolumn{7}{|c|}{$\%$ Larval mortality after } \\
\hline & 0-day & 1-day & 3-day & 5-day & 8-day & 10-day & 12-day \\
\hline Control & 0 & $0^{\mathrm{d}}$ & $0^{d}$ & $0^{\mathrm{d}}$ & $0^{\mathrm{d}}$ & $0^{\mathrm{d}}$ & $0^{\mathrm{b}}$ \\
\hline 150 & 0 & $8^{c}$ & $24^{c}$ & $42^{c}$ & $77^{c}$ & $89^{c}$ & $100^{\mathrm{a}}$ \\
\hline 250 & 0 & $13^{b}$ & $49^{b}$ & $61^{\mathrm{b}}$ & $86^{\mathrm{b}}$ & $93^{b}$ & $100^{\mathrm{a}}$ \\
\hline 350 & 0 & $18^{\mathrm{a}}$ & $58^{\mathrm{a}}$ & $74^{\mathrm{a}}$ & $91^{\mathrm{a}}$ & $100^{\mathrm{a}}$ & - \\
\hline $\mathrm{LSD}_{0.05}$ & - & 3.552 & 2.824 & 2.306 & 1.631 & 2.105 & - \\
\hline
\end{tabular}

Means in the same row followed by the same letter are not significantly different at $p<0.05$.

\subsection{Cowpea aphid, A. craccivora.}

Adults and nymphs of the cowpea aphid, A. craccivora were exposed to gamma irradiation doses of 150, 250 and $350 \mathrm{~Gy}$. Tested insects were completely killed at zero day after treatment.

\section{Efficacy of tested biocide, B. thuringiensis against some insect pests.}

The biocide compound, $B$. thuringiensis was exposed to gamma irradiation doses of $150,250 \& 350 \mathrm{~Gy}$ and evaluated against the pests of $P$. gossypiella, S. littoralis and $A$. craccivora.

\subsection{Pink bollworm, P. gossypiella:}

\subsubsection{Newly hatched larvae:}

Gamma irradiation doses of 150, 250 and 350 Gy was potentiated the efficacy of the biocide compound, Protecto ( $B$. thuringiensis) against the newly hatched larvae of the pink bollworm as shown in Table (4). The $\mathrm{LC}_{50}$ were $0.45,0.29,0.07$ and 0.052 $\mathrm{gm} / \mathrm{L}$ for the Protecto, Protecto $+150 \mathrm{~Gy}$, Protecto $+250 \mathrm{~Gy}$ and Protecto $+350 \mathrm{~Gy}$, respectively on newly hatched larvae after 6 hours. The $\mathrm{LC}_{50}$ was lower in the 
irradiated Protecto than the untreated. The toxicity index of the tested biocide was 100 according to $\mathrm{LC}_{50}$ and $\mathrm{LC}_{90}$ of Protecto $+350 \mathrm{~Gy}$ that considered the most effective treatment, followed by Protecto +250 Gy (74.3 and $47.03 \%)$, Protecto + 150 Gy (17.9 and 21.01\%), then unexposed Protecto (11.6 and 8.38\%) that considered the least effective treatment. The $\mathrm{LC}_{50}$ was decreased at 72 hours after treatment. The $\mathrm{LC}_{50}$, were $0.25,0.06,0.04$ and $0.001 \mathrm{gm} / \mathrm{L}$ when the newly hatched larvae treated by Protecto, Protecto +150 Gy, Protecto +250 Gy and Protecto +350 Gy, respectively.

\subsubsection{Fourth instars larvae:}

Data in Table (4) indicated that Protecto +350 Gy was the most potent compound after one hour from exposure, the $\mathrm{LC}_{50}$ was $89.62 \mathrm{gm} / \mathrm{L}$, followed by Protecto + 250 Gy (111.1 gm/L), Protecto + $150 \mathrm{~Gy}(123.1 \mathrm{gm} / \mathrm{L})$ and unexposed Protecto $(164.1 \mathrm{gm} / \mathrm{L})$. The toxicity index of the biocide treatments based on $\mathrm{LC}_{50}$ and $\mathrm{LC}_{90}$ was 100 for Protecto $+350 \mathrm{~Gy}$ against the $4^{\text {th }}$ instar larvae of the pink bollworm, followed by Protecto +250 Gy (toxicity index $=80.7$ and $75.3 \%$ ), Protecto +150 Gy (toxicity index $=72.8$ and $63.7 \%$ ) and unexposed Protecto biocide (toxicity index= 54.6 and $57.7 \%$ ). It was noticed that gamma irradiation doses were potentiated biocide the $B$. thuringiensis efficacy.

The $L C_{50}$ value was decreased at 72 hours after treatment. The $L C_{50}$ were 96.6, $22.49,12.19$ and $11.59 \mathrm{gm} / \mathrm{L}$ when the $4^{\text {th }}$ instar larvae treated by Protecto, Protecto +150 Gy, Protecto +250 Gy and Protecto +350 Gy, respectively.

\subsection{Cotton leafworm, S. littoralis:}

The $4^{\text {th }}$ instar larvae of the cotton leafworm treated by Protecto recorded, the $\mathrm{LC}_{50}$ of $190.8 \mathrm{gm} / \mathrm{L}$, but the Protecto exposed to gamma irradiation doses of 150, 250 and 350 Gy had potentiated effects, LC $_{50}$ 's were $75.31,118.2$ and $156.2 \mathrm{gm} / \mathrm{L}$ for Protecto +150 Gy, Protecto +250 Gy and Protecto +350 Gy, respectively (Table 5). Protecto +150 Gy was the most potent compound (toxicity index $=100 \%$ ) according to $\mathrm{LC}_{50}$ and $\left.\mathrm{LC}_{90}\right)$. While, the Protecto exposed to gamma dose of $250 \mathrm{~Gy}$ had decreased effect (toxicity index $=63.7$ and $50.6 \%$ ) according to $\mathrm{LC}_{50}$ and $\mathrm{LC}_{90}$, followed by Protecto $+350 \mathrm{~Gy}$ (toxicity index $=48.2$ and $36.04 \%$ ) compared with Protecto +150 Gy.

\subsection{Cowpea aphid, A, crassivora:}

The adults and nymphs of cowpea aphid were treated by Protecto, Protecto +150 Gy, Protecto +250 Gy and Protecto +350 Gy (Table 5). Gamma irradiation doses caused potentiating effect on the Protecto efficiency especially dose of $350 \mathrm{~Gy}$, followed by Protecto +250 Gy and Protecto $+150 \mathrm{~Gy}\left(\mathrm{LC}_{50}=16.40,41.17\right.$ and 49.04 $\mathrm{gm} / \mathrm{L})$ compared with unexposed Protecto, (101.5 gm/L). 
Table 4. Efficacy of the tested biocide exposed to gamma doses against pink bollworm larvae.

\begin{tabular}{|c|c|c|c|c|}
\hline \multirow{2}{*}{ Treatments } & \multirow{2}{*}{$\begin{array}{c}\mathrm{LC}_{50}(\mathrm{gm} / \mathrm{L}) \\
95 \% \text { Confidence limits }\end{array}$} & \multirow{2}{*}{$\begin{array}{c}\mathrm{LC} \mathrm{C}_{90}(\mathrm{gm} / \mathrm{L}) \\
95 \% \text { Confidence limits }\end{array}$} & \multicolumn{2}{|c|}{ Toxicity index } \\
\hline & & & $\mathrm{LC}_{50}$ & $\mathrm{LC}_{90}$ \\
\hline \multicolumn{5}{|c|}{ Newly hatched larvae after 6 hours } \\
\hline Protecto & $\begin{array}{c}0.45 \\
0.19 \pm 0.68 \\
\end{array}$ & $\begin{array}{c}9.65 \\
5.08 \pm 12.8 \\
\end{array}$ & 11.6 & 8.38 \\
\hline Protecto+150 Gy & $\begin{array}{c}0.29 \\
0.11 \pm 0.46 \\
\end{array}$ & $\begin{array}{c}3.85 \\
2.57 \pm 8.52 \\
\end{array}$ & 17.9 & 21.01 \\
\hline Protecto+250 Gy & $\begin{array}{c}0.07 \\
0.0004 \pm 0.184\end{array}$ & $\begin{array}{c}1.72 \\
1.11 \pm 4.09 \\
\end{array}$ & 74.3 & 47.03 \\
\hline Protecto+350 Gy & $\begin{array}{c}0.052 \\
0.0006 \pm 0.174\end{array}$ & $\begin{array}{c}0.809 \\
0.476 \pm 1.184\end{array}$ & 100 & 100 \\
\hline \multicolumn{5}{|c|}{ Newly hatched larvae after 72 hours } \\
\hline Protecto & $\begin{array}{c}0.25 \\
0.19 \pm 0.48\end{array}$ & $\begin{array}{c}7.11 \\
3.08 \pm 16.8\end{array}$ & 4.0 & 8.54 \\
\hline Protecto+150 Gy & $\begin{array}{c}0.06 \\
0.01 \pm 0.33\end{array}$ & $\begin{array}{c}2.23 \\
0.57 \pm 4.22\end{array}$ & 16.7 & 27.2 \\
\hline Protecto+250 Gy & $\begin{array}{c}0.04 \\
0.0002 \pm 0.127 \\
\end{array}$ & $\begin{array}{c}1.24 \\
1.01 \pm 3.05 \\
\end{array}$ & 25.0 & 48.9 \\
\hline Protecto+350 Gy & $\begin{array}{c}0.01 \\
0.0004 \pm 0.198\end{array}$ & $\begin{array}{c}0.607 \\
0.356 \pm 1.081\end{array}$ & 100 & 100 \\
\hline \multicolumn{5}{|c|}{$4^{\text {th }}$ instars larvae after one hour } \\
\hline Protecto & $\begin{array}{c}164.1 \\
115.4 \pm 346.5\end{array}$ & $\begin{array}{c}555.1 \\
166.2 \pm 987.5\end{array}$ & 54.6 & 57.7 \\
\hline Protecto+150 Gy & $\begin{array}{c}123.1 \\
118.7 \pm 416.3\end{array}$ & $\begin{array}{c}502.3 \\
136.9 \pm 839.0\end{array}$ & 72.8 & 63.7 \\
\hline Protecto+250 Gy & $\begin{array}{c}111.1 \\
75.93 \pm 389.2\end{array}$ & $\begin{array}{c}425.1 \\
126.9 \pm 652.3\end{array}$ & 80.7 & 75.3 \\
\hline Protecto+350 Gy & $\begin{array}{c}89.62 \\
41.15 \pm 272.1\end{array}$ & $\begin{array}{c}320.1 \\
102.9 \pm 635.5\end{array}$ & 100 & 100 \\
\hline \multicolumn{5}{|c|}{$4^{\text {th }}$ instars larvae after 72 hour } \\
\hline Protecto & $\begin{array}{c}96.6 \\
231.4 \pm 626.8\end{array}$ & $\begin{array}{c}368.2 \\
166.2 \pm 582.5\end{array}$ & 11.9 & 30.3 \\
\hline Protecto+150 Gy & $\begin{array}{c}22.49 \\
15.38 \pm 32.56\end{array}$ & $\begin{array}{c}343.6 \\
355.9 \pm 1139\end{array}$ & 51.5 & 32.5 \\
\hline Protecto+250 Gy & $\begin{array}{c}12.19 \\
5.853 \pm 29.51\end{array}$ & $\begin{array}{c}217.6 \\
259.9 \pm 952.3\end{array}$ & 95.1 & 51.3 \\
\hline Protecto+350 Gy & $\begin{array}{c}11.59 \\
4.562 \pm 22.13\end{array}$ & $\begin{array}{c}111.7 \\
96.9 \pm 535.5\end{array}$ & 100 & 100 \\
\hline
\end{tabular}

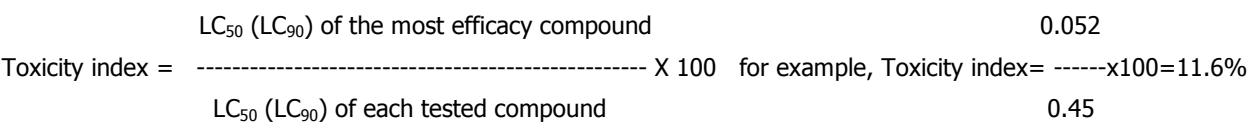

Reviewing the above mentioned results, it could be concluded in general that Protecto compound ( $B$. thuringiences) can be succefully used against the tested insect pests. Also, gamma irradiation was potentiated the efficacy of the biocide, Protecto and improved its potency when exposed to the doses of 150, 250 and $350 \mathrm{~Gy}$. 
Thus, Protecto +350 Gy proved the best treatment used to decrease the $\mathrm{LC}_{50}$ on the pink bollworm larvae and cowpea aphid adults $\&$ nymphs. While, Protecto +150 Gy, followed by Protecto +250 Gy and Protecto +350 Gy achieved the best potencies than unexposed Protecto on the cotton leafworm.

Amer (2006) reported that the combination of gamma irradiation with Dipel $2 x$ (Bacillus thuringiences, Kurstaki) activated the spores of biocide compound and caused a potentiating effect when Dipel-2x exposed to gamma irradiation doses of 5, 10, 20, $40 \& 80 \mathrm{~Gy}$ against the newly hatched larvae and eggs of the pink bollworm in both laboratory and field experiments during 2004 and 2005 cotton season. All treatments increased fiber and seed weights of the cotton crop.

Table 5. Efficacy of the biocide compound exposed to gamma doses against cotton leafworm larvae and cowpea aphid adults and nymphs.

\begin{tabular}{|c|c|c|c|c|}
\hline \multirow{2}{*}{ Treatments } & \multirow{2}{*}{$\begin{array}{c}\mathrm{LC} \mathrm{C}_{50}(\mathrm{gm} / \mathrm{L}) \\
95 \% \text { Confidence limits }\end{array}$} & \multirow{2}{*}{$\begin{array}{c}\mathrm{LC}_{90}(\mathrm{gm} / \mathrm{L}) \\
95 \% \text { Confidence limits }\end{array}$} & \multicolumn{2}{|c|}{ Toxicity index } \\
\hline & & & $\mathrm{LC}_{50}$ & $\mathrm{LC}_{90}$ \\
\hline \multicolumn{5}{|c|}{$4^{\text {th }}$ instars larvae of the cotton leafworm } \\
\hline Protecto & $\begin{array}{c}190.8 \\
179.43 \pm 247.7\end{array}$ & $\begin{array}{c}940.4 \\
145.6 \pm 1355\end{array}$ & 39.5 & 27.02 \\
\hline Protecto+150 Gy & $\begin{array}{c}75.31 \\
52.64 \pm 95.12 \\
\end{array}$ & $\begin{array}{c}254.1 \\
180.1 \pm 300.7\end{array}$ & 100 & 100 \\
\hline Protecto+250 Gy & $\begin{array}{c}118.2 \\
108.2 \pm 146.5\end{array}$ & $\begin{array}{c}502.2 \\
246.4 \pm 777.5\end{array}$ & 63.7 & 50.6 \\
\hline Protecto+350 Gy & $\begin{array}{c}156.2 \\
128.7 \pm 198.3 \\
\end{array}$ & $\begin{array}{c}705.1 \\
378.1 \pm 999.7\end{array}$ & 48.2 & 36.04 \\
\hline \multicolumn{5}{|c|}{ Adults and nymphs of the cowpea aphids } \\
\hline Protecto & $\begin{array}{c}101.5 \\
63.9 \pm 201.1 \\
\end{array}$ & $\begin{array}{c}269.9 \\
183.4 \pm 935.1 \\
\end{array}$ & 16.2 & 10.6 \\
\hline Protecto+150 Gy & $\begin{array}{c}49.04 \\
32.41 \pm 104.6\end{array}$ & $\begin{array}{c}245.8 \\
104.5 \pm 366.8\end{array}$ & 33.4 & 11.6 \\
\hline Protecto+250 Gy & $\begin{array}{c}41.17 \\
23.47 \pm 62.54 \\
\end{array}$ & $\begin{array}{c}56.1 \\
42.94 \pm 94.62 \\
\end{array}$ & 39.8 & 50.8 \\
\hline Protecto+350 Gy & $\begin{array}{c}16.40 \\
10.3 \pm 29.8\end{array}$ & $\begin{array}{c}28.48 \\
15.5 \pm 42.3\end{array}$ & 100 & 100 \\
\hline
\end{tabular}

$$
\text { Toxicity index }=\frac{\mathrm{LC}_{50}\left(\mathrm{LC}_{90}\right) \text { of the most efficacy compound }}{-\mathrm{LC}_{50}\left(\mathrm{LC}_{90}\right) \text { of each tested compound }}
$$




\section{REFERENCES}

1. Abbott, W.S. 1925. A method of computing the effectiveness of an insecticide. J. Econ. Entomol. 18: 265-267.

2. Amer, R.A. 2006. Combination of gamma irradiation with Bacillus thuringiensis (Kurs.) and the synergistic effect of two bioinsecticid mixture for controlling the pink bollworm, Pectinophora gossypiella (Saund.) in cotton bolls. J.Egypt.Ger.Soc.Zool. 51: 1-13.

3. Amer, R., A. and I .H. El -Nemaky. 2008. Effect of Some Biocides on the Biological and Prediction Parameters of the Pink Bollworm, Pectinophora gossypiella (Saund.) (Order:Lepidoptera- Family:Gelechiidae). Egyptian Journal of Biological Pest Control, 18(1), 2008, 61-70. Proceeding of $2^{\text {nd }}$ Arab Conference of Applied Biological Pest Control, Cairo, Egypt, 7-10 April 2008.

4. Chen, Z.H., L.J. Chen, Y.L. Zhang and Z.J. Wu. 2011. Microbial properties, enzyme activities and the persistence of exogenous proteins in soil under consecutive cultivation of transgenic cottons (Gossypium hirsutum L.). Plant Soil Env., 57(2): 67-74.

5. Costat Statistical Software (1990): Microcomputer program analysis version 4.20 , cohort Software, Berkeley, CA.

6. Dennehye, J.J., J. Grannett and T.F. Leigh. 1983. Relevance of slide-dip and residual bioassay comparisons to detection of resistance in spider mites. $J$. Econ. Entomol., 76: 1225-1230.

7. Duncan, D.B. 1955. Multiple ranges and multiple F.test. Biomerics. 11:1-42.

8. El-Defrawi, M. E. , A. Toppozada, N. Mansour and M. Zeid. 1964. Toxicological studies on the Egyptian cotton leafworm, Prodenia litura I. Susceptibility of different larval instars to insecticides. J. Econ. Entomol. 57: 591-593.

9. Hatem, A. E., S. S. Abdel-Samad, H. A. Saleh, M. H. Soliman and A. I. Hussien. 2009.Toxicologyical and physiological activity of plant extracts against Spodoptra littoralis (Boisduval) (Lepidoptra: Noctuidae) larvae. Bol. San. Veg. Plagas 35: 517-531.

10. Moy, J.H., B. Chinnasri, B.S. Sipes, D.P. Schmit, R.T. Hamasaki, E.F. Mersino and R.M. Yamakawa. 1997. Radiation disinfection or disinfestations of nematodes, aphids, mites, thrips and other pests on food plant materials: Evaluation for effectiveness and product quality. Proceeding of a final Research Co- ordination meeting 3-7 November.p. 105-114. 
11. Pawar, V. M. and P. S. Borikar. 2005. Microbial options for the management of Helicoverpa armigera (Hubner) Indian Society of Pulses Research and Development, IIPR, Kanpur 193-231.

12. Rabindra, R. J. and B. Ramanujam. 2007. Microbial control of sucking pests using entomopathogenic fungi. Journal of Biological Control., 21: 21-28.

13. Rashad, M.A. and E.D. Ammar. 1985. Mass rearing of the the spiny bollworm, Earias insulana (Boisd.) on semi artificial diet. Bull.Soc.Ent.Egypt, 65: 239244.

14. Sallam, H.A. and S.M. Ibrahim. 1993. Inherited sterility in progeny of gamma irradiated male cotton leafworm, Spodoptera littoralis (Boisd.). Proceeding of the final research co-ordination meeting. Phonix, Arizona, 9-13 september.

15. Saranya, S., R. Ushakumari, J. Sosamma and P. Babum. 2010. Efficacy of different entomopathogenic fungi against cow pea aphid, Aphis crassivora (Koch). Journal of Biopesticides, 3: 138-142.

16. Soon, L.G. 1986. Diamondback moth management (Proc. $1^{\text {st }}$ Int. Workshop), Asian Research and Development Center. Taipei: 159.

17. Sun, Y. P. 1950. Toxicity index on improved method of comparing the relative toxicity of insecticides. J. Econ. Entomol., 43: 45-53. 


\section{تأثير معاملات أشعة جاما مع المبيد الحيوى باسيلس ثورينجينسيزعلى بعض الآفات الحشرية فى المعل}

رضا عبد الجليل محمد عامر ، مجدى عبد العظيم أحمد ، عادل السيد حاتم

$$
\text { معهد بحوث وقاية النباتات - مركز البحوث الزراعية - دقى - جيزة - ج.م.ع }
$$

أجريت هذه التجربة معمليا عام 2010 بمعهر بحوث وقاية النباتات حيث تم تعريض الآفات المختبرة والمركب الحيوى البروتكتو لجرعات مختلفة من أثعة جاما. نم تعريض يرقات الفقس الحديث والعمر الرابع لدودة اللوز القرنفلية ويرقات العمر الرابع لدودة ورق القطن وكذلك الأطوار البالغة

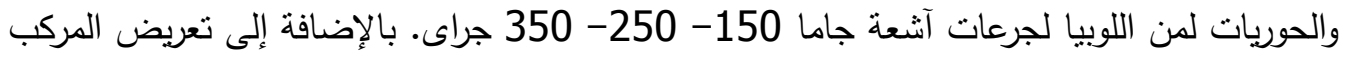
الحيوى بروتكتو إلى نفس الجرعات من أثنعة جاما. تم تقدير الفعل الابادى للمعاملات: البروتكتو بروتكتو +150 جراى - بروتكتو +250 جراى - بروتكتو +350 جراى ضد نفس الآنات. أدت جرعات آثنعة جاما 150 - 250- 350 جراى إلى زيادة النسبة المئوية لموت يرقات جرات الفقس الحديث لدودة اللوز القرنفلية الى 52 - 56 - 58\% على التوالى فى نفس يوم التعريض ووصلت

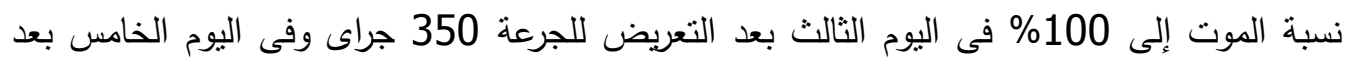
التعريض للجرعات 250 و150 جراى. كما وصلت النسبة المئوية للموت فى الطور البرقى الرابع لدودة اللوز القرنفلية إلى 100\% فى اليوم الثامن و العانشر بعد التعريض. بينما وصلت نسبة الموت 100\% فى يرقات دودة ورق القطن فى اليوم العاشر و الثانى عشر بعد التعريض. أما الأطوار البالغة وحوريات من اللوبيا فقد حدث لها 100\% موت فى نفس يود التعريض. عندما نم تعريض المركب الحيوى البروتكتو لجرعات آشعة جاما 150- 250- 350 جراى حدثت تقوية فى فعالية المركب الحيوى على يرقات الفقس الحديث والعمر الرابع لدودة اللوز القرنفلية

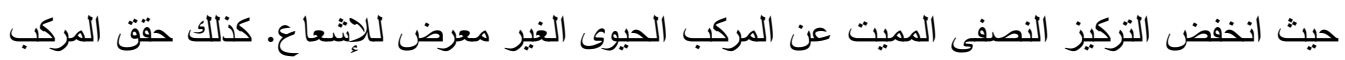
المعرض للإثعاع كفاءة إبادية عالية فى حالة معاملة الأطوار البالغة وحوريات المن خاصنة معاملة البروتكتو + 350 جراى يليه فى ذلك البروتكتو + 250 جراى ثم البروتكتو + 150 جراى عن عن

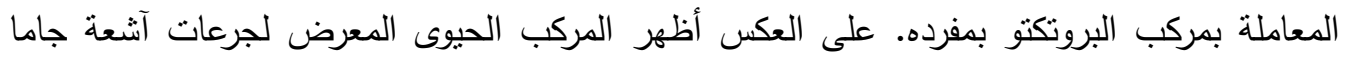
(البروتكتو +150 جراى - البروتكتو +250 جراى - البروتكتو +350 جراى) والمستخدمة ضد بردئ برقات دودة ورق القطن إلى زيادة فى قيم التركيزالنصفى المميت كلما زادت جرعة آشعة جاما المعرض لهاي الها المركب الحيوى ولكنها أعطت جرعات نصفية مميتة أقل مقارنة بالمركب الحيوى بمفرده دون التعرض التها 